\title{
Effect of lactoperoxidase on the antimicrobial effectiveness of the thiocyanate hydrogen peroxide combination in a quantitative suspension test
}

\author{
A Welk*1, Ch Meller ${ }^{2}$, R Schubert ${ }^{3}$, Ch Schwahn ${ }^{1}$, A Kramer ${ }^{4}$ and H Below ${ }^{4}$
}

Address: ${ }^{1}$ Department of Restorative Dentistry, Periodontology and Endodontology, Dental School, University of Greifswald, Greifswald, Germany, ${ }^{2}$ Department of Operative Dentistry and Periodontology, Center of Dentistry, Oral Medicine, and Maxillofacial Surgery, University Hospital Tuebingen, Tuebingen, Germany, ${ }^{3}$ Private dental practice, Berlin, Germany and ${ }^{4}$ Institute of Hygiene and Environmental Medicine, University of Greifswald, Greifswald, Germany

Email: AWelk* - welk@uni-greifswald.de; Ch Meller - christian.meller@med.uni-tuebingen.de; R Schubert - ron.schubert@gmx.de; Ch Schwahn - schwahn@uni-greifswald.de; A Kramer - kramer@uni-greifswald.de; H Below - Below@uni-greifswald.de

* Corresponding author

Published: 9 July 2009

BMC Microbiology 2009, 9:134 doi:10.1/86/147|-2/80-9-134
Received: 8 September 2008

Accepted: 9 July 2009

This article is available from: http://www.biomedcentral.com//47/-2/80/9//34

(C) 2009 Welk et al; licensee BioMed Central Ltd.

This is an Open Access article distributed under the terms of the Creative Commons Attribution License (http://creativecommons.org/licenses/by/2.0), which permits unrestricted use, distribution, and reproduction in any medium, provided the original work is properly cited.

\begin{abstract}
Background: The positive antimicrobial effects of increasing concentrations of thiocyanate (SCN) and $\mathrm{H}_{2} \mathrm{O}_{2}$ on the human peroxidase defence system are well known. However, little is known about the quantitative efficacy of the human peroxidase thiocyanate $\mathrm{H}_{2} \mathrm{O}_{2}$ system regarding Streptococcus mutans and sanguinis, as well as Candida albicans. The aim of this study was to evaluate the effect of the enzyme lactoperoxidase on the bactericidal and fungicidal effectiveness of a thiocyanate- $\mathrm{H}_{2} \mathrm{O}_{2}$ combination above the physiological saliva level. To evaluate the optimal effectiveness curve, the exposure times were restricted to I, 3, 5, and I5 min.
\end{abstract}

Results: The bactericidal and fungicidal effects of lactoperoxidase on Streptococcus mutans and sanguinis and Candida albicans were evaluated by using two test mixtures of a $2.0 \%$ (w/v; $0.34 \mathrm{M}$ ) thiocyanate and $0.4 \%(w / v ; 0.12 \mathrm{M})$ hydrogen peroxide solution, one without and one with lactoperoxidase. Following the quantitative suspension tests (EN 1040 and EN 1275), the growth of surviving bacteria and fungi in a nutrient broth was measured. The reduction factor in the suspension test without lactoperoxidase enzyme was $<$ I for all three tested organisms. Thus, the mixtures of $2.0 \%(\mathrm{w} / \mathrm{v} ; 0.34 \mathrm{M})$ thiocyanate and $0.4 \%(\mathrm{w} / \mathrm{v} ; 0.12 \mathrm{M})$ hydrogen peroxide had no in vitro antimicrobial effect on Streptococcus mutans and sanguinis or Candida albicans. However, the suspension test with lactoperoxidase showed a high bactericidal and fungicidal effectiveness in vitro.

Conclusion: The tested thiocyanate and $\mathrm{H}_{2} \mathrm{O}_{2}$ mixtures showed no relevant antimicrobial effect. However, by adding lactoperoxidase enzyme, the mixtures became not only an effective bactericidal (Streptococcus mutans and sanguinis) but also a fungicidal (Candida albicans) agent.

\section{Background}

Maintaining daily oral hygiene is essential to prevent caries, gingivitis, and periodontitis [1-3]. To support mechanical plaque control, which is mostly insufficient [4-6], antiseptics are used in toothpastes and mouth rinses [7-10]. 
However, the concentrations and frequency of use of antiseptics are limited to avoid side effects, such as discoloration of teeth and tongue, taste alterations, mutations $[11,12]$, and, for microbiostatic active agents, the risk of developing resistance or cross-resistance against antibiotics [13]. Therefore, it would seem better to stimulate or support the innate host defence system, such as the oral peroxidase-thiocyanate-hydrogen peroxide system.

Human saliva contains peroxidase enzymes and lysozyme, among other innate host defence systems. The complete peroxidase system in saliva comprises three components: the peroxidase enzymes (glycoprotein enzyme), salivary peroxidase (SPO) from major salivary glands and myeloperoxidase (MPO) from polymorphonuclear leucocytes filtering into saliva from gingival crevicular fluid; hydrogen peroxide $\left(\mathrm{H}_{2} \mathrm{O}_{2}\right)$; and an oxidizable substrate such as the pseudohalide thiocyanate ( $\left.\mathrm{SCN}^{-}\right)$ from physiological sources $[14,15]$. SPO is almost identical to the milk enzyme lactoperoxidase (LPO) $[16,17]$. All these peroxidase enzymes catalyze the oxidation of the salivary thiocyanate ion ( $\mathrm{SCN}-)$ by hydrogen peroxide $\left(\mathrm{H}_{2} \mathrm{O}_{2}\right)$ to OSCN- and the corresponding acid hypothiocyanous acid ( $\mathrm{HOSCN}$ ), $\mathrm{O}_{2} \mathrm{SCN}^{-}$, and possibly $\mathrm{O}_{3} \mathrm{SCN}^{-}[18]$, which have been shown to inhibit bacterial [19-23], fungal [24], and viral viability [25]. However, the system is effective only if its components are sufficiently available in saliva. Salivary concentration of $\mathrm{SCN}^{-}$varies considerably and depends, for instance, on diet and smoking habits. The normal range of salivary $\mathrm{SCN}$ - for nonsmokers is from 0.5 to $2 \mathrm{mM}(29-116 \mathrm{mg} / \mathrm{l})$, but in smokers $[26,27]$, the level can be as high as $6 \mathrm{mM}(348 \mathrm{mg} / \mathrm{l})$. Pruitt et al. [28], for example, see the main limiting component for the production of the oxidation products of $\mathrm{SCN}^{-}$in whole saliva to be the hydrogen peroxide $\left(\mathrm{H}_{2} \mathrm{O}_{2}\right)$ concentration. Thomas et al. [29] showed that the combination of LPO, $\mathrm{SCN}^{-}$, and $0.3 \mathrm{mM}(10.2 \mathrm{mg} / \mathrm{l}) \mathrm{H}_{2} \mathrm{O}_{2}$ caused complete inhibition that lasted for nearly $16 \mathrm{~h}$, whereas $0.3 \mathrm{mM}$ (10.2 mg/l) $\mathrm{H}_{2} \mathrm{O}_{2}$ alone had no effect. However, if no more $\mathrm{H}_{2} \mathrm{O}_{2}$ was added, the concentration of the inhibitor OSCN- fell because of slow decomposition of $\mathrm{OSCN}^{-}$, and, when OSCN-fell below $0.01 \mathrm{mM}(0.74 \mathrm{mg} / \mathrm{l})$, the bacteria resumed metabolism and growth. The loss of OSCN- over time is based on decomposition, not on the reaction with bacteria [29].

The typical concentration of peroxidases in whole saliva is roughly $5 \mu \mathrm{g} / \mathrm{ml}$, whereas the MPO concentration $(3.6 \mu \mathrm{g} /$ $\mathrm{ml})$ is approximately twice the amount of SPO $(1.9 \mu \mathrm{g} /$ $\mathrm{ml}$ ) [30]. Therefore, even if SPO is deficient, MPO activity would probably be adequate for SCN- oxidation in mixed saliva [30]. The study by Adolphe et al. [31] showed that the lactoperoxidase system's antimicrobial efficiency can be enhanced by better concentration ratios of the LPO system components. However, this finding was postulated for only near physiological conditions and did not consider a concentration of thiocyanate and $\mathrm{H}_{2} \mathrm{O}_{2}$ higher than the physiological one.

Rosin et al. [32] showed that, in the saliva peroxidase system, increasing $\mathrm{SCN}-/ \mathrm{H}_{2} \mathrm{O}_{2}$ above its physiologic saliva level reduced plaque and gingivitis significantly compared to baseline values and a placebo. A new dentifrice formulated on these results showed the same effects regarding plaque and gingivitis prevention in comparison to a benchmark product containing triclosan [33]. However, the effects were not sufficient to recommend using the SPO system to effectively prevent oral diseases in the long run.

Thus, the question arose, Is it possible to increase antimicrobial effectiveness by adding not just thiocyanate and hydrogen peroxide but also LPO to oxidize as much the $\mathrm{SCN}-$ anions as possible to become an effective antimicrobial agent? Therefore, we conducted a standardized quantitative suspension test at a fixed concentration level of all three components above the physiological one to evaluate the influence of LPO on the lactoperoxidase-thiocyanatehydrogen peroxide system relative to its bactericidal and fungicidal effectiveness against Streptococcus mutans and sanguinis and Candida albicans.

\section{Results}

The reduction factors (RF) of the test suspensions without and with LPO on the viability of Streptococcus mutans, Streptococcus sanguinis, and Candida albicans at different time points $(1,3,5$, and $15 \mathrm{~min})$ are shown in tables $1,2 \& 3$.

The accompanying suspension tests with single components (SCN-, LPO) and combinations of two components $(\mathrm{LPO}+\mathrm{SCN}-, \mathrm{LPO}+\mathrm{H} 2 \mathrm{O} 2)$ showed no clinically relevant effects $(\mathrm{RF} \leq 0.3)$ at all time points. Only the single component $\mathrm{H} 2 \mathrm{O} 2$ showed a reduction factor of 1.5 after 15 $\min$.

\section{Streptococcus mutans}

The antibacterial reductions of the thiocyanate-hydrogen peroxide system without LPO increased with time and were statistically significantly different between 5 and 15 $\min$. However, they remained at a very low level $(\mathrm{RF}<1)$. Thus, the suspension without LPO had practically no bactericidal effectiveness. The suspension with LPO showed a distinct antibacterial reduction (RF 7.49) after $5 \mathrm{~min}$, which means the complete killing of all cells. Thus, a further increase of the reduction factor was not possible. The comparison between groups A (without LPO) and B (with LPO) showed a statistically significant difference in favour of group B after 5 and 15 min (Table 1). 
Table I: Reduction factors of the test thiocyanate hydrogen peroxide microbial suspension without and with LPO to Streptococcus mutans at different time points.

\begin{tabular}{|c|c|c|c|c|c|c|c|c|c|}
\hline \multirow{3}{*}{ Time } & \multicolumn{4}{|l|}{$\begin{array}{l}\text { Group A } \\
\text { Without LPO }\end{array}$} & \multicolumn{4}{|l|}{$\begin{array}{l}\text { Group B } \\
\text { With LPO }\end{array}$} & \multirow[t]{3}{*}{$A$ vs. $B^{2}$} \\
\hline & \multirow[t]{2}{*}{ Reduction factor } & \multicolumn{3}{|c|}{ Comparisons within $\mathrm{A}^{\prime}$} & \multirow[t]{2}{*}{ Reduction Factor } & \multicolumn{3}{|c|}{ Comparisons within $\mathrm{B}^{\prime}$} & \\
\hline & & I vs. 3 & 3 vs. 5 & 5 vs. 15 & & I vs. 3 & 3 vs. 5 & 5 vs. 15 & \\
\hline [min] & Mean \pm SD & $\mathrm{P}$ & $\mathrm{P}$ & $\mathrm{P}$ & Mean \pm SD & $\mathrm{P}$ & $P$ & $\mathrm{P}$ & $P$ \\
\hline I & $0.23 \pm 0.26$ & \multirow{2}{*}{0.844} & & & $0.03 \pm 0.17$ & \multirow{2}{*}{0.016} & & & 0.128 \\
\hline 3 & $0.21 \pm 0.36$ & & \multirow{2}{*}{0.375} & & $0.53 \pm 0.22$ & & \multirow{2}{*}{0.016} & & 0.026 \\
\hline 5 & $0.25 \pm 0.12$ & & & \multirow{2}{*}{0.016} & $7.49 \pm 0.64^{3}$ & & & \multirow{2}{*}{0.375} & $<0.001$ \\
\hline 15 & $0.69 \pm 0.43$ & & & & $7.41 \pm 0.69^{3}$ & & & & $<0.001$ \\
\hline
\end{tabular}

1) Wilcoxon test with a significant level of $<0.05$

2) Mann-Whitney $U$ test with a significance level of $<0.001$

3) Complete killing of all cells in test suspension

\section{Streptococcus sanguinis}

The antibacterial reductions of the thiocyanate-hydrogen peroxide system without LPO increased with time but only to a very low level ( $\mathrm{RF} \leq 1)$ with practically no bactericidal effectiveness. The suspension with LPO showed an effective antibacterial reduction after $5 \mathrm{~min}$ (RF $4.01 \pm$ 3.88 ) and after $15 \mathrm{~min}$ (RF $8.12 \pm 0.22$ ). The RFs between 3 and 5 min were statistically significantly different. The comparison between groups A and B showed a statistically significant difference in favour of B (with LPO) after 15 min (Table 2).

\section{Candida albicans}

The antifungal reduction of the thiocyanate-hydrogen peroxide system without LPO (Group A) increased with time but only to a very low level $(\mathrm{RF}<1)$ with practically no fungicidal effectiveness. The suspension with LPO (Group B) showed an effective fungicidal reduction after 3 min (RF $6.78 \pm 0.25$ ), which means the complete killing of all microbes. Thus, a further increase of the reduction factor was not possible.

Table 2: Reduction factors of the test thiocyanate hydrogen peroxide microbial suspension without and with LPO to Streptococcus sanguinis at different time points.

\begin{tabular}{|c|c|c|c|c|c|c|c|c|c|}
\hline \multirow{3}{*}{ Time } & \multicolumn{4}{|l|}{$\begin{array}{l}\text { Group A } \\
\text { Without LPO }\end{array}$} & \multicolumn{4}{|l|}{$\begin{array}{l}\text { Group B } \\
\text { With LPO }\end{array}$} & \multirow[t]{3}{*}{$A$ vs. $B^{2}$} \\
\hline & \multirow[t]{2}{*}{ Reduction factor } & \multicolumn{3}{|c|}{ Comparisons within $\mathrm{A}^{\prime}$} & \multirow[t]{2}{*}{ Reduction Factor } & \multicolumn{3}{|c|}{ Comparisons within $\mathrm{B}^{\mathrm{I}}$} & \\
\hline & & I vs. 3 & 3 vs. 5 & 5 vs. 15 & & I vs. 3 & 3 vs. 5 & 5 vs. 15 & \\
\hline [min] & Mean \pm SD & $\mathrm{P}$ & $\mathrm{P}$ & $\mathrm{P}$ & Mean \pm SD & $\mathrm{P}$ & $\mathrm{P}$ & $\mathrm{P}$ & $\mathrm{P}$ \\
\hline 1 & $0.10 \pm 0.90$ & \multirow{2}{*}{0.609} & & & $0.13 \pm 0.12$ & \multirow{2}{*}{0.078} & & & 0.710 \\
\hline 3 & $0.16 \pm 0.15$ & & \multirow{2}{*}{0.109} & & $0.78 \pm 0.67$ & & \multirow{2}{*}{0.016} & & 0.073 \\
\hline 5 & $0.27 \pm 0.17$ & & & \multirow{2}{*}{0.016} & $4.01 \pm 3.88$ & & & \multirow{2}{*}{0.063} & 0.073 \\
\hline 15 & $1.03 \pm 0.60$ & & & & $8.12 \pm 0.22^{3}$ & & & & $<0.001$ \\
\hline
\end{tabular}

I) Wilcoxon test with a significant level of $<0.05$

2) Mann-Whitney $U$ test with a significance level of $<0.00$ I

3) Complete killing of all cells in test suspension 
Table 3: Reduction factors of the test thiocyanate hydrogen peroxide suspension without and with LPO to Candida albicans at different time points.

\begin{tabular}{|c|c|c|c|c|c|c|c|c|c|}
\hline \multirow{3}{*}{ Time } & \multicolumn{4}{|l|}{$\begin{array}{l}\text { Group A } \\
\text { Without LPO }\end{array}$} & \multicolumn{4}{|l|}{$\begin{array}{l}\text { Group B } \\
\text { With LPO }\end{array}$} & \multirow[t]{3}{*}{$A$ vs. $B^{2}$} \\
\hline & \multirow[t]{2}{*}{ Reduction factor } & \multicolumn{3}{|c|}{ Comparisons within $\mathrm{A}^{\prime}$} & \multirow[t]{2}{*}{ Reduction Factor } & \multicolumn{3}{|c|}{ Comparisons within $\mathrm{B}^{\prime}$} & \\
\hline & & I vs. 3 & 3 vs. 5 & 5 vs. 15 & & I vs. 3 & 3 vs. 5 & 5 vs. 15 & \\
\hline$[\mathrm{min}]$ & Mean \pm SD & $\mathrm{P}$ & $\mathrm{P}$ & $\mathrm{P}$ & Mean \pm SD & $\mathrm{P}$ & $\mathrm{P}$ & $\mathrm{P}$ & $\mathrm{P}$ \\
\hline I & $0.12 \pm 0.19$ & \multirow{2}{*}{0.496} & & & $0.43 \pm 0.33$ & \multirow{2}{*}{0.004} & & & 0.077 \\
\hline 3 & $0.26 \pm 0.26$ & & \multirow{2}{*}{0.141} & & $6.78 \pm 0.25^{3}$ & & \multirow{2}{*}{0.551} & & $<0.001$ \\
\hline 5 & $0.15 \pm 0.13$ & & & \multirow{2}{*}{0.004} & $6.75 \pm 0.22^{3}$ & & & \multirow{2}{*}{1.000} & $<0.001$ \\
\hline 15 & $0.93 \pm 0.58$ & & & & $6.74 \pm 0.26^{3}$ & & & & $<0.001$ \\
\hline
\end{tabular}

1) Wilcoxon test with a significant level of $<0.05$

2) Mann-Whitney $U$ test with a significance level of $<0.00$ I

3) Complete killing of all cells in test suspension

The RFs between 3 and 5 min were statistically significantly different. The comparison between groups A and B showed a statistically significant difference in favour of $B$ (with LPO) after 3 min (Table 3).

\section{Discussion}

The applied quantitative suspension tests are recognized European norm tests for evaluating bactericidal (EN 1040 ) and fungicidal efficacy (EN 1275) of a newly developed antiseptic $[34,35]$. In contrast to common antimicrobial tests (inhibition tests), these quantitative suspension tests facilitate, for example, the strict distinctions between bacteriostatic/fungistatic and bacteriocidal/ fungicidal effects by neutralizing the active agent. The tests are also useful for determining a quantitative curve for concentration and time of an antiseptic. Thus, the tests are suitable for evaluating the effect of LPO on the lactoperoxidase-thiocyanate-hydrogen peroxide system's antimicrobial effects. However, the results must be interpreted within the limitations of an in vitro test.

The industrially produced LPO enzyme such as that used in toothpaste [36] was used because of its reproducible quality. Human SPO is slightly different from industrially produced LPO. However, the main characteristics of the industrially produced LPO are identical to saliva peroxidase $[16,17]$. Based on this similarity, industrially produced LPO is used instead of SPO in studies and is often referred to as LPO in the literature [37].

The efficiency of the LPO system depends - besides the concentration of its components - on exposure time and $\mathrm{pH}$ value $[29,31]$. Therefore, to determine when the LPO system or the oxidation products reached their initial opti- mal bactericidal and fungicidal effectiveness, tests were conducted at the exposure times of 1,3,5, and $15 \mathrm{~min}$.

All tests were conducted at the $\mathrm{pK}_{\mathrm{a}}(\mathrm{pH} 5.3)$ of HOSCN/ OSCN- [38], because pretests showed that the lactoperoxidase-thiocyanate-hydrogen peroxide system was effective at $5.3 \mathrm{pH}$. Lumikari et al. [23] found the optimum $\mathrm{pH}$ to be about 5.0. Increasing the HOSCN/OSCN- concentration by adding $\mathrm{H}_{2} \mathrm{O}_{2}$ could raise the inhibition of Streptococcus mutans in human saliva $[21,36]$ but only at a $\mathrm{pH}$ around 5 and not at neutral $\mathrm{pH}$ because of the shift of OSCN- to HOSCN by a low $\mathrm{pH}$ value in favour of HOSCN. Unlike OSCN-', HOSCN has no charge, which facilitates penetration through the lipophilic bacterial cell membrane and raises the antimicrobial effectiveness of the saliva antiperoxidase system [18]. Thus, the most effective product of the LPO system works around the $\mathrm{pH}$, where the biofilm/saliva pH level is pathologically effective.

To completely ensure that the tested effect of the lactoperoxidase enzyme on the thiocyanate-hydrogen peroxide system above the physiological concentration level was not based primarily on single components $\left(\mathrm{H}_{2} \mathrm{O}_{2}, \mathrm{SCN}^{-}\right.$, $\mathrm{LPO})$ or on combination of two components $\left(\mathrm{LPO}+\mathrm{SCN}^{-}\right.$ , $\mathrm{LPO}+\mathrm{H}_{2} \mathrm{O}_{2}$ ), accompanying suspension tests were conducted.

With one exception, all accompanying single component tests showed no clinically relevant antimicrobacterial effectiveness (RF: $\leq 0.3$ ). Only the single component $\mathrm{H}_{2} \mathrm{O}_{2}$ showed a moderate reduction factor of 1.5 after 15 min. This result is in line with the known bactericidal effect of $\mathrm{H}_{2} \mathrm{O}_{2}$ [29]. However, in combination with LPO, the effect of $\mathrm{H}_{2} \mathrm{O}_{2}$ was reduced compared to its single 
effect. We assume that the radicals, which are produced by the reaction of LPO with $\mathrm{H}_{2} \mathrm{O}_{2}$ [39], are short-lived intermediates that cannot react bactericidally under the test conditions.

All suspension tests without LPO at all time points showed no or no clinically relevant antimicrobial effectiveness (highest RF: Streptococcus mutans 0.6, Streptococcus sanguinis 1.0, and Candida albicans 0.9). The low reduction potential could be based on $\mathrm{H}_{2} \mathrm{O}_{2}$ itself or, to a small extent, on the oxidation without enzyme of SCN- to OSCN- by $\mathrm{H}_{2} \mathrm{O}_{2}$, especially at higher exposure times.

On the other hand, all suspensions with LPO showed remarkably high antimicrobial effectiveness. In the quantitative suspension test, the lactoperoxidase-thiocyanatehydrogen peroxide system (group B) showed its maximal reduction (complete) of Streptococcus mutans (RF 7.49) after a 5-min incubation time. Both reduction factors (after 5 and $15 \mathrm{~min}$ ) were statistically significantly different from group A (without LPO).

The results show the large effect of the LPO enzyme on antibacterial effectiveness of the lactoperoxidase-thiocyanate-hydrogen peroxide system, which can be a powerful bactericide, not just bacteriostatic, if all components are above their physiological levels. It is assumed that the effect is based on not just the described shift of OSCN- to HOSCN (pH 5.3) [38] but also a higher amount of the more effective LPO-caused oxidation products, $\mathrm{O}_{2} \mathrm{SCN}^{-}$ and $\mathrm{O}_{3} \mathrm{SCN}^{-}[21,23,28]$.

In the case of Streptococcus sanguinis, the reduction factor at $5 \mathrm{~min}$ (RF 4.01) was statistically significantly higher in comparison with the reduction factor at $3 \mathrm{~min}$ ( $\mathrm{RF}$ 0.78) of Group B (with LPO). However, there was no statistically significant difference between the reduction factors at $5 \mathrm{~min}$ in either group (A and B), despite a great difference in their mean values. The reason was the large standard deviation of in RF $(4.01 \pm 3.88)$.

We assume that, when the 5-min measurement was taken, the bactericidal effect by HOSCN/OSCN- was already occurring in some experiments but not yet in others. One of the reasons could be the NAD(P)H-OSCN- oxidoreductase system, which Streptococcus mutans and Streptococcus sanguinis and other bacteria have. This system can reduce $\mathrm{HOSCN} / \mathrm{OSCN}^{-}$to the less effective components, SCN- and $\mathrm{H}_{2} \mathrm{O}_{2}$. Streptococcus sanguinis has more of this reducing enzyme than does Streptococcus mutans. Thus, we assume that a higher concentration of $\mathrm{HOSCN} / \mathrm{OSCN}^{-}$ is needed to achieve a similar bactericidal effect on Streptococcus sanguinis than on Streptococcus mutans $[40,41]$, meaning more time in the experiment. After $15 \mathrm{~min}$, the test suspension with LPO had a similar antibacterial effec- tiveness on Streptococcus sanguinis ( $R F 8.12 \pm 0.22$ ) as on Streptococcus mutans (RF $7.41 \pm 0.69)$.

Rosin et al. [32] used more than the physiological level of $\mathrm{SCN}-\mathrm{H}_{2} \mathrm{O}_{2}$ in a toothpaste to increase the human oral defence system. This toothpaste reduced gingivitis and inhibited plaque. The enhancement of these effects by an optimal combination not only of $\mathrm{H}_{2} \mathrm{O}_{2}$ and thiocyanate, but also of LPO enzyme, for mouth rinses or toothpaste formula is certainly possible and should be considered in further clinical studies.

In our study, the LPO system was bactericidal at pH 5.3 to Streptococcus mutans and sanguinis. However, experiments by Thomas et al. [29] showed that the LPO system was effectively bacteriostatic, but not bactericidal, at pH 7 during a 1-h incubation. This finding may mean that the LPO system might shift from bacteriostatic to bactericidal at a point when the Streptococcus mutans causes low $\mathrm{pH}$ $(<5.5)$, leading, for example, to demineralisation of tooth hard substances. Thus, the system could be a reservoir, getting its highest antibacterial activity when it is most needed: at a point when $\mathrm{pH}$ falls as a result of bacterial lactic acid production.

After $3 \mathrm{~min}$, the reduction of Candida albicans in the test suspension with LPO was already complete. Thus, of the three tested microorganisms, Candida albicans was most sensitive to the lactoperoxidase-thiocyanate-hydrogen peroxide system, even if it was buffered by phosphate. Majerus and Courtois [42], as well as Samant et al. [43], could not find a sufficient antifungal effect of the SCN-$\mathrm{H}_{2} \mathrm{O}_{2}$-LPO system. Lenander-Lumikari [22] found that C. albicans is sensitive to HOSCN/OSCN-, but saliva and salivary concentrations of phosphate blocked the antifungal effect of the peroxidase systems. However, they used all components of this system at the physiological human saliva level.

Thus, the lactoperoxidase-thiocyanate-hydrogen peroxide system can be not only fungistatic [44] but also fungicidal for Candida albicans; independently, it is phosphate-buffered at salivary concentrations or higher.

C. albicans can be isolated from the mouth of most individuals, but the fungus causes oral disease such as oral mucositis in primarily immunocompromised individuals [45-47]. Further, Candida albicans is seen as a reservoir for pneumonia [48] and intestinal related diseases [49].

Theraud et al. [50] showed that chlorhexidine was fungicidal on pure cultures, yeast mixtures, and biofilms above a concentration level of $0.5 \%(\mathrm{w} / \mathrm{w})$. However, Pitten et al. [51] showed that treatment with a $0.3 \%(w / w)$ chlorhexidine-based product did not provide a clinical benefit 
for cancer patients with chemotherapy-induced leukopenia. In their study, the risk of mucositis and clinical sequelae (e.g., C-reactive protein) seemed to be enhanced by chlorhexidine mouth rinse, although the counts of microorganisms on the oral mucous membranes were significantly reduced. They assumed that the reason was the reduced tissue tolerance to chlorhexidine. This assumption is supported by a study that showed a discrepancy between antiseptic activity and clinical effect on radiationinduced [52] or chemo-induced mucositis [53] by chlorhexidine mouth rinse compared with placebo. In a peritoneal explant test for evaluating tissue tolerance, chlorhexidine showed the highest cytotoxicity in comparison to an essential oil and an amine/stannous fluoride mouth rinse [54]. Thus, it could be interesting to increase host innate defence systems, such as the lactoperoxidasethiocyanate-hydrogen peroxide system, which have no or low effectiveness at the physiological level, by increasing their level of concentration instead of using common antiseptics.

\section{Conclusion}

In summary, in the quantitative suspension test, the $\mathrm{SCN}^{-}$ and $\mathrm{H}_{2} \mathrm{O}_{2}$ mixture above normal physiological saliva levels showed little or no antimicrobial effect within $15 \mathrm{~min}$. However, by adding lactoperoxidase enzyme, the tested mixtures became not only an effective bactericidal (Streptococcus mutans and sanguinis) but also a fungicidal (Candida albicans) agent. Thus, all three components of the LPO-system are needed for its microbicidal effect. Subsequent studies should consider loading tests with human saliva and different concentrations of all three components.

\section{Methods}

The study was performed based on the European norms (EN) 1040 and EN 1275. A 9.9-ml test solution (with and without LPO) was mixed with a $0.1-\mathrm{ml}$ bacteria or fungus suspension (overnight culture) and stored at $37^{\circ} \mathrm{C}$.

After 1, 3, 5, and 15 min contact time, the test mixture was again well mixed (vortexed), and $1 \mathrm{ml}$ was transferred into $9 \mathrm{ml}$ of neutralizer (polysorbate $8030 \mathrm{~g} / \mathrm{L}$, lecithin $3 \mathrm{~g} / \mathrm{L}$, L-histidine $1 \mathrm{~g} / \mathrm{L}$, sodium thiosulfate $5 \mathrm{~g} / \mathrm{L}$, aqua bidestillata ad $1000 \mathrm{~mL}$ ). The neutralizer was tested in a prestudy according to the recommended neutralization test of the German Society for Hygiene and Microbiology (DGHM).

After $5 \mathrm{~min}$ of neutralization time, $1.0 \mathrm{ml}$ of the neutralized test suspension was mixed with $9.0 \mathrm{ml}$ of dilution solution, and $0.1 \mathrm{ml}$ of this final solution was spread on tryptone soya agar (TSA, Oxoid, Germany) plates. After $42-48 \mathrm{~h}$ of aerobic incubation at $36^{\circ} \mathrm{C}\left( \pm 1^{\circ} \mathrm{C}\right)$, macroscopically visible colonies were counted on the plates. The arithmetic means of the duplicates were calculated with the plates of 15-300 colony-forming units (cfu) as recom- mended by European norms. Every trial was conducted separately seven times, and the arithmetic means with the corresponding standard deviations were calculated.

Before each experiment was conducted, all components were prepared as follows.

\section{Test organisms}

Preservation and culture of the test organisms (Streptococcus mutans ATCC 35668, sanguinis ATCC 10556, and Candida albicans ATCC 10231) were conducted corresponding largely to EN 1040 and EN 1275 (adjusted number of cells in the suspension: $1.5 \times 10^{8}-5.0 \times 10^{8}$ $\mathrm{cfu} / \mathrm{ml}$ for bacteria and $1.5 \times 10^{7}-5.0 \times 10^{7} \mathrm{cfu} / \mathrm{ml}$ for fungi).

\section{Solutions of test mixtures}

Buffer adjusted to pH 5.3: 7 parts $0.2 \mathrm{M} \mathrm{KH}_{2} \mathrm{PO}_{4}, 1$ part $0.2 \mathrm{M} \mathrm{K}_{2} \mathrm{HPO}_{4} ; \mathrm{SCN}^{-}$solution $(2 \% \mathrm{w} / \mathrm{v} ; 0.34 \mathrm{M}): 2.8 \mathrm{~g}$ $\mathrm{NaSCN} / 100 \mathrm{ml}$ freshly glass-distilled water; $\mathrm{H}_{2} \mathrm{O}_{2}$ solution $(0.4 \% \mathrm{w} / \mathrm{v} ; 0.12 \mathrm{M}): 1.12 \mathrm{~g}$ carbamide peroxide $\left(\mathrm{CH}_{4} \mathrm{~N}_{2} \mathrm{O} \cdot \mathrm{H}_{2} \mathrm{O}_{2}\right) / 100 \mathrm{ml}$ glass-distilled water (prepared immediately before the trial); buffer-LPO solution: $5.0 \mathrm{mg}$ LPO $(210 \mathrm{U} / \mathrm{mg}$, Fluka) dissolved in $0.250 \mathrm{ml}$ glycerine and $0.250 \mathrm{ml}$ phosphate buffer saline solution, adding 5 $\mathrm{ml}$ of the buffer to $\mathrm{pH} 5.3$.

\section{Test mixtures and control}

Group A contained $5.0 \mathrm{ml}$ buffer solution (pH 5.3), 2.5 ml SCN- solution $(2.0 \% \mathrm{w} / \mathrm{v} ; 0.34 \mathrm{M})$, and $2.5 \mathrm{ml} \mathrm{H}_{2} \mathrm{O}_{2}$ solution $(0.4 \% \mathrm{w} / \mathrm{v} ; 0.12 \mathrm{M})$; Group B contained $4.0 \mathrm{ml}$ buffer solution (pH 5.3), $2.5 \mathrm{ml} \mathrm{SCN}$ - solution $(2.0 \% \mathrm{w} /$ $\mathrm{v} ; 0.34 \mathrm{M}), 2.5 \mathrm{ml} \mathrm{H}_{2} \mathrm{O}_{2}$ solution $(0.4 \% \mathrm{w} / \mathrm{v} ; 0.12 \mathrm{M})$, and $1 \mathrm{ml}$ buffered-LPO solution. Thus, the LPO concentration in this solution was $83 \mathrm{mg} / \mathrm{ml}$.

The control group contained $5.0 \mathrm{ml}$ buffer solution $(\mathrm{pH}$ 5.3 ) and $5.0 \mathrm{ml}$ water with standardized hardness. All prepared solutions were stored at $37^{\circ} \mathrm{C}$ until use.

In the same manner, all single components $\left(\mathrm{H}_{2} \mathrm{O}_{2}, \mathrm{SCN}^{-}\right.$, $\mathrm{LPO})$ or their combinations $\left(\mathrm{LPO}+\mathrm{SCN}^{-}, \mathrm{LPO}+\mathrm{H}_{2} \mathrm{O}_{2}\right.$ ) were tested for their antimicrobial effects in accompanying suspension tests.

\section{Statistical analysis}

The microbial counts were expressed as their decimal logarithms. The reduction factor (RF) was calculated as follows:

$$
\lg R F=\lg \left(c_{u}\right)-\lg \left(\mathrm{cfu} \mathrm{t}_{\mathrm{A} / \mathrm{B}}\right),
$$

where cfu $\mathrm{c}=$ number of $\mathrm{cfu}$ per $\mathrm{ml}$ control medium (water with standardized hardness), and $\mathrm{cfu}_{\mathrm{A} / \mathrm{B}}=$ number of cfu per ml test group A or B. 
The comparisons at the time points between groups A and $B$ (without and with LPO, respectively) were performed with the Mann-Whitney U test and within groups with the Wilcoxon test. All statistical analyses were carried out with SPSS 11.5.

\section{Authors' contributions}

AW, HB, and AK participated in the design and coordination of the study, supervised the study, and analyzed the data. RS performed most of the laboratory work with the assistance of ChM and HB. ChS carried out the statistical analysis. AW wrote the manuscript. All authors read and approved the final version of the manuscript.

\section{Acknowledgements}

We thank David Armbruster, Scientific Editing, University of Tennessee Health Science Center, for final copyediting.

\section{References}

I. Loe H, Silness J: Periodontal Disease in Pregnancy. I. Prevalence and Severity. Acta Odontol Scand 1963, 21:533-551.

2. Lindhe J, Hamp SE, Loe H: Plaque induced periodontal disease in beagle dogs. A 4-year clinical, roentgenographical and histometrical study. J Periodontal Res 1975, I 0(5):243-255.

3. Axelsson P, Lindhe J, Nystrom B: On the prevention of caries and periodontal disease. Results of a I5-year longitudinal study in adults. J Clin Periodontol I991, I 8(3): 182-189.

4. De la Rosa M, Zacarias Guerra J, Johnston DA, Radike AW: Plaque growth and removal with daily toothbrushing. J Periodontol | 979, 50( I 2):66|-664.

5. Brown RS, Schwabacher KL: Much dentistry qualifies for medical insurance. Dent Econ I991, 81(3):33-34. 36

6. Hugoson A, Norderyd O, Slotte $C$, Thorstensson $\mathrm{H}$ : Oral hygiene and gingivitis in a Swedish adult population 1983 and 1993. Clin Periodontol 1973, 25(10):807-8I2.

7. Frandsen A: Mechanical and hygiene practices. In Dental plaque control measures and oral hygiene practices Edited by: Löe HK. D.V. Oxford: IRL Pr; 1986:93-116.

8. Mandel ID: Chemotherapeutic agents for controlling plaque and gingivitis. J Clin Periodontol I988, I 5(8):488-498.

9. Kocher T, Sawaf H, Warncke M, Welk A: Resolution of interdental inflammation with 2 different modes of plaque control. J Clin Periodontol 2000, 27( I 2):883-888.

10. Welk A, Splieth CH, Schmidt-Martens G, Schwahn C, Kocher T, Kramer A, Rosin M: The effect of a polyhexamethylene biguanide mouthrinse compared with a triclosan rinse and a chlorhexidine rinse on bacterial counts and 4-day plaque regrowth. J Clin Periodontol 2005, 32(5):499-505.

II. Addy M: Chlorhexidine compared with other locally delivered antimicrobials. A short review. I Clin Periodontol 1986, 13(10):957-964.

12. Grassi TF, Camargo EA, Salvadori DM, Marques ME, Ribeiro DA: DNA damage in multiple organs after exposure to chlorhexidine in Wistar rats. Int J Hyg Environ Health 2007, 2 1 0(2): 163-167.

13. Russell AD: Plasmids and bacterial resistance to biocides. Journal of Applied Microbiology 1997, 83(2): 155-165.

14. Morrison M, Steele WF: Lactoperoxidase, the peroxidase in the salivary gland. In Biology of the mouth Edited by: Person P. Washington, D.C.: American Association for the Advancement of Science; 1968.

15. Thomas EL, Bozeman PM, Learn DB: Lactoperoxidase: structure and catalytic properties. In Peroxidases in Chemistry and Biology Edited by: Everse J, Everse KE, Grisham MB. Boca Raton, FL.: CRC Press; 1991:123-142.

16. Mansson-Rahemtulla B, Rahemtulla F, Humphreys-Beher MG: Human salivary peroxidase and bovine lactoperoxidase are cross-reactive. J Dent Res 1990, 69(1 2): |839-1846.

17. Ihalin R, Loimaranta $V$, Tenovuo J: Origin, structure, and biological activities of peroxidases in human saliva. Arch Biochem Biophys 2006, 445(2):26I-268.
18. Thomas EL: Lactoperoxidase-catalyzed oxidation of thiocyanate: equilibria between oxidized forms of thiocyanate. Biochemistry I98I, 20(II):3273-3280.

19. Courtois P, Majerus P, Labbe M, Abbeele A Vanden, Yourassowsky E, Pourtois M: Susceptibility of anaerobic microorganisms to hypothiocyanite produced by lactoperoxidase. Acta Stomatol Belg 1992, 89(3): I55-I62.

20. Germaine GR, Tellefson LM: Effect of human saliva on glucose uptake by Streptococcus mutans and other oral microorganisms. Infect Immun I98I, 3 I (2):598-607.

21. Mansson-Rahemtulla B, Baldone DC, Pruitt KM, Rahemtulla F: Effects of variations in $\mathrm{pH}$ and hypothiocyanite concentrations on S. mutans glucose metabolism. J Dent Res 1987, 66(2):486-49।.

22. Tenovuo J, Anttilla O, Lumikari M, Sievers G: Antibacterial effect of myeloperoxidase against Streptococcus mutans. Oral Microbiol Immunol 1988, 3(2):68-7I.

23. Lumikari M, Soukka T, Nurmio S, Tenovuo J: Inhibition of the growth of Streptococcus mutans, Streptococcus sobrinus and Lactobacillus casei by oral peroxidase systems in human saliva. Arch Oral Biol I99I, 36(2): I55-160.

24. Lenander-Lumikari M: Inhibition of Candida albicans bythe Peroxidase/SCN-/H2O2 system. Oral Microbiol Immunol 1992, 7(5):315-320.

25. Mikola $H$, Waris $M$, Tenovuo J: Inhibition of herpes simplex virus type I, respiratory syncytial virus and echovirus type II by peroxidase-generated hypothiocyanite. Antiviral Res 1995, 26(2): $|6|-|7|$.

26. Tenovuo J, Makinen KK: Concentration of thiocyanate and ionizable iodine in saliva of smokers and nonsmokers. J Dent Res 1976, 55(4):66I-663.

27. Lamberts BL, Pruitt KM, Pederson ED, Golding MP: Comparison of salivary peroxidase system components in caries-free and caries-active naval recruits. Caries Res 1984, I 8(6):488-494.

28. Pruitt KM, Tenovuo J, Fleming W, Adamson M: Limiting factors for the generation of hypothiocyanite ion, an antimicrobial agent, in human saliva. Caries Res 1982, 16(4):315-323.

29. Thomas EL, Milligan TW, Joyner RE, Jefferson MM: Antibacterial activity of hydrogen peroxide and the lactoperoxidasehydrogen peroxide-thiocyanate system against oral streptococci. Infect Immun 1994, 62(2):529-535.

30. Thomas EL, Jefferson MM, Joyner RE, Cook GS, King CC: Leukocyte myeloperoxidase and salivary lactoperoxidase: identification and quantitation in human mixed saliva. J Dent Res 1994, 73(2):544-555.

31. Adolphe Y, Jacquot M, Linder M, Revol-Junelles AM, Milliere JB: Optimization of the components concentrations of the lactoperoxidase system by RSM. J Appl Microbiol 2006, 100(5): 1034-1042.

32. Rosin M, Kocher T, Kramer A: Effects of SCN-/H2O2 combinations in dentifrices on plaque and gingivitis. J Clin Periodontol 200I, 28(3):270-276

33. Rosin M, Kramer A, Bradtke D, Richter G, Kocher T: The effect of a SCN-/H>2O2 toothpaste compared to a commercially available triclosan-containing toothpaste on oral hygiene and gingival health - a 6-month home-use study. J Clin Periodontol 2002, 29( I 2): 1086-1091.

34. EN 1040 Chemical disinfectants and antiseptics. Basic bactericidal activity. Test method and requirements (phase I). Beuth-Publishing, Berlin; 1997.

35. EN I275 Chemical disinfectants and antiseptics. Basic fungicidal activity. Test method and requirements (phase I). Beuth-Publishing, Berlin; 1997.

36. Lenander-Lumikari M, Tenovuo J, Mikola H: Effects of a lactoperoxidase system-containing toothpaste on levels of hypothiocyanite and bacteria in saliva. Caries Res 1993, 27(4):285-291.

37. Reiter B, Härnulv G: Lactoperoxidase antibacterial system: natural occurrence, biological functions and practical applications. J Food Prot 1984, 47:724-732.

38. Tenovuo J, Pruitt KM, Mansson-Rahemtulla B, Harrington P, Baldone DC: Products of thiocyanate peroxidation: properties and reaction mechanisms. Biochim Biophys Acta 1986, 870(3):377-384.

39. Kohler $\mathrm{H}$, Jenzer $\mathrm{H}$ : Interaction of lactoperoxidase with hydrogen peroxide. Formation of enzyme intermediates and generation of free radicals. Free Radic Biol Med 1989, 6(3):323-339.

40. Hoogendoorn H, Piessens JP, Scholtes W, Stoddard LA: Hypothiocyanite ion; the inhibitor formed by the system lactoperoxi- 
dase-thiocyanate-hydrogen peroxide. I. Identification of the inhibiting compound. Caries Res 1977, I I(2):77-84.

41. Carlsson J, Iwami Y, Yamada T: Hydrogen peroxide excretion by oral streptococci and effect of lactoperoxidase-thiocyanatehydrogen peroxide. Infect Immun 1983, 40(I):70-80.

42. Majerus PM, Courtois PA: Susceptibility of Candida albicans to peroxidase-catalyzed oxidation products of thiocyanate, iodide and bromide. J Biol Buccale 1992, 20(4):24I-245.

43. Samant PA, Jefferson MM, Thomas EL: Lactoperoxidase antimicrobial activity against Candida albicans. J Dent Res 1999, 78(Spec. Iss): I 208.

44. Benoy MJ, Essy AK, Sreekumar B, Haridas M: Thiocyanate mediated antifungal and antibacterial property of goat milk lactoperoxidase. Life Sci 2000, 66(25):2433-2439.

45. Belazi M, Velegraki A, Koussidou-Eremondi T, Andreadis D, Hini S, Arsenis G, Eliopoulou C, Destouni E, Antoniades D: Oral Candida isolates in patients undergoing radiotherapy for head and neck cancer: prevalence, azole susceptibility profiles and response to antifungal treatment. Oral Microbiol Immunol 2004, 1 9(6):347-35I.

46. Nicolatou-Galitis $O$, Dardoufas $K$, Markoulatos $P$, Sotiropoulou-Lontou A, Kyprianou K, Kolitsi G, Pissakas G, Skarleas C, Kouloulias V, Papanicolaou $V$, et al:: Oral pseudomembranous candidiasis, herpes simplex virus-I infection, and oral mucositis in head and neck cancer patients receiving radiotherapy and granulocyte-macrophage colony-stimulating factor (GM-CSF) mouthwash. J Oral Pathol Med 200I, 30(8):47I-480.

47. Gomes MF, Kohlemann KR, Plens G, Silva MM, Pontes EM, da Rocha JC: Oral manifestations during chemotherapy for acute lymphoblastic leukemia: a case report. Quintessence Int 2005, 36(4):307-3।3.

48. Yamamoto T, Ueta E, Kamatani T, Osaki T: DNA identification of the pathogen of candidal aspiration pneumonia induced in the course of oral cancer therapy. I Med Microbiol 2005, 54(Pt 5):493-496.

49. Zollner-Schwetz I, Auner HW, Paulitsch A, Buzina W, Staber PB, Ofner-Kopeinig P, Reisinger EC, Olschewski H, Krause R: Oral and Intestinal Candida Colonization in Patients Undergoing Hematopoietic Stem-Cell Transplantation. J Infect Dis 2008, 198(I): I50-153.

50. Theraud M, Bedouin Y, Guiguen C, Gangneux JP: Efficacy of antiseptics and disinfectants on clinical and environmental yeast isolates in planktonic and biofilm conditions. J Med Microbiol 2004, 53(Pt 10): 1013-1018.

5I. Pitten FA, Kiefer T, Buth C, Doelken G, Kramer A: Do cancer patients with chemotherapy-induced leukopenia benefit from an antiseptic chlorhexidine-based oral rinse? A doubleblind, block-randomized, controlled study. J Hosp Infect 2003, 53(4):283-29I.

52. Foote RL, Loprinzi CL, Frank AR, O'Fallon JR, Gulavita S, Tewfik HH, Ryan MA, Earle JM, Novotny P: Randomized trial of a chlorhexidine mouthwash for alleviation of radiation-induced mucositis. I Clin Oncol 1994, I 2( I 2):2630-2633.

53. Potting CM, Uitterhoeve R, Op Reimer WS, Van Achterberg T: The effectiveness of commonly used mouthwashes for the prevention of chemotherapy-induced oral mucositis: a systematic review. Eur J Cancer Care (Engl) 2006, I5(5):43 I-439.

54. Welk A, Rosin M, Ludtke C, Schwahn C, Kramer A, Daeschlein G: The peritoneal explant test for evaluating tissue tolerance to mouthrinses. Skin Pharmacol Physiol 2007, 20(3):162-166.
Publish with Biomed Central and every scientist can read your work free of charge

"BioMed Central will be the most significant development for disseminating the results of biomedical research in our lifetime. "

Sir Paul Nurse, Cancer Research UK

Your research papers will be:

- available free of charge to the entire biomedical community

- peer reviewed and published immediately upon acceptance

- cited in PubMed and archived on PubMed Central

- yours - you keep the copyright
BioMedcentral 